\title{
Article
}

\section{Dietary Fibre Intake Is Associated with Serum Levels of Uraemic Toxins in Children with Chronic Kidney Disease}

\author{
Amina El Amouri ${ }^{1, *}$, Evelien Snauwaert ${ }^{1}(0)$, Aurélie Foulon ${ }^{2}$, Charlotte Vande Moortel ${ }^{2}$, Maria Van Dyck ${ }^{3}$, \\ Koen Van Hoeck ${ }^{4}$, Nathalie Godefroid ${ }^{5}$, Griet Glorieux ${ }^{2}{ }^{\oplus}$, Wim Van Biesen ${ }^{2}$, Johan Vande Walle ${ }^{1}$, \\ Ann Raes ${ }^{1,+}+\mathbb{D}$ and Sunny Eloot ${ }^{2,+}+\mathbb{C}$
}

1 Paediatric Nephrology and Rheumatology Section, Department of Paediatrics, Ghent University Hospital, Corneel Heymanslaan 10, 9000 Ghent, Belgium; Evelien.Snauwaer@@UZGent.Be (E.S.);

Johan.VandeWalle@uzgent.be (J.V.W.); ann.raes@ugent.be (A.R.)

2 Nephrology Section, Department of Internal Medicine and Paediatrics, Ghent University Hospital, Corneel Heymanslaan 10, 9000 Ghent, Belgium; aurelie.foulon@telenet.be (A.F.); charlotte.vandemoortel@ugent.be (C.V.M.); Griet.Glorieux@UGent.be (G.G.); wim.vanbiesen@uzgent.be (W.V.B.); Sunny.Eloot@UGent.be (S.E.)

3 Paediatric Nephrology Section, Department of Paediatrics, University Hospitals Leuven (Campus Gasthuisberg), Herestraat 49, 3000 Leuven, Belgium; maria.vandyck@uzleuven.be

4 Paediatric Nephrology Section, Department of Paediatrics, Antwerp University Hospital, Wilrijkstraat 10, 2650 Edegem, Belgium; koen.van.hoeck@uza.be

5 Paediatric Nephrology Section, Department of Paediatrics, Cliniques Universitaires St. Luc, Université Catholique Louvain, Avenue Hippocrate 10, 1200 Brussels, Belgium; nathalie.godefroid@uclouvain.be

* Correspondence: amina.elamouri@uzgent.be

$\dagger$ Contributed equally to the study.

Citation: El Amouri, A.; Snauwaert, E.; Foulon, A.; Vande Moortel, C.; Van Dyck, M.; Van Hoeck, K.; Godefroid, N.; Glorieux, G.; Van Biesen, W.; Vande Walle, J.; et al. Dietary Fibre Intake Is Associated with Serum Levels of Uraemic Toxins in Children with Chronic Kidney Disease. Toxins 2021, 13, 225. https://doi.org/ $10.3390 /$ toxins 13030225

Received: 19 February 2021

Accepted: 17 March 2021

Published: 19 March 2021

Publisher's Note: MDPI stays neutral with regard to jurisdictional claims in published maps and institutional affiliations.

Copyright: (C) 2021 by the authors Licensee MDPI, Basel, Switzerland. This article is an open access article distributed under the terms and conditions of the Creative Commons Attribution (CC BY) license (https:/ / creativecommons.org/licenses/by/ $4.0 /)$.

\begin{abstract}
Imbalanced colonic microbial metabolism plays a pivotal role in generating protein-bound uraemic toxins (PBUTs), which accumulate with deteriorating kidney function and contribute to the uraemic burden of children with chronic kidney disease (CKD). Dietary choices impact the gut microbiome and metabolism. The aim of this study was to investigate the relation between dietary fibre and gut-derived PBUTs in paediatric CKD. Sixty-one ( 44 male) CKD children ( $9 \pm 5$ years) were prospectively followed for two years. Dietary fibre intake was evaluated by either $24-\mathrm{h}$ recalls (73\%) or 3-day food records (27\%) at the same time of blood sampling for assessment of total and free serum levels of different PBUTs using liquid chromatography. We used linear mixed models to assess associations between fibre intake and PBUT levels. We found an inverse association between increase in fibre consumption (g/day) and serum concentrations of free indoxyl sulfate $(-3.1 \%$ $(-5.9 \% ;-0.3 \%)(p=0.035))$, free p-cresyl sulfate $(-2.5 \%(-4.7 \% ;-0.3 \%)(p=0.034))$, total indole acetic acid (IAA) $(-1.6 \%(-3.0 \% ;-0.3 \%)(p=0.020))$, free IAA $(-6.6 \%(-9.3 \% ;-3.7 \%)(p<0.001))$, total serum p-cresyl glucuronide (pCG) $(-3.0 \%(-5.6 \% ;-0.5 \%)(p=0.021))$ and free pCG levels $(-3.3 \%(-5.8 \% ;-0.8 \%)(p=0.010))$. The observed associations between dietary fibre intake and the investigated PBUTs highlight potential benefits of fibre intake for the paediatric CKD population. The present observational findings should inform and guide adaptations of dietary prescriptions in children with CKD.
\end{abstract}

Keywords: chronic kidney disease; children; diet; fibre intake; uraemic toxins

Key Contribution: Fibre intake has been underappreciated in traditional nutritional CKD management; In this context; awareness should be raised among clinicians that current dietary instructions inadvertently limit fibre intake; which may in turn lead to increased uraemic toxin levels.

\section{Introduction}

Chronic kidney disease (CKD) in children is a micro-inflammatory state, affecting nearly every organ system and resulting into an increased morbidity and high mortality, 
along with a decreased quality of life [1-4]. The exact pathophysiological mechanisms underlying the complex and multifactorial paediatric uraemic syndrome are still poorly understood. In recent years, it was postulated that the accumulation of organic waste products with failing kidney function, is one of the key contributors of uraemic illness [5]. A large number of these uraemic toxins arise from protein fermentation by the gut microbiota and circulate in the blood bound to albumin [5-7]. Two of the most studied protein-bound uraemic toxins (PBUTs), indoxyl sulfate (IxS) and p-cresyl sulfate (pCS), might be promising targets for adjuvant toxin-reductive strategies [8]. Accruing observational and experimental studies suggest that these two toxins, as well as the less studied p-cresyl glucuronide (pCG) and indole acetic acid (IAA), are associated with poor cardiovascular outcomes and kidney disease progression [8-12].

The link between the gut and the kidney seems to be bidirectional, since uraemic patients also seem to have a unique dysbiotic colon microenvironment with profoundly altered composition and metabolism of gut microbes and prolonged transit time $[8,13-16]$. As the intestinal microbial metabolism is largely driven by nutrient availability, it was postulated that dietary interventions could reduce toxin generation [16,17]. A higher intake of dietary fibre may be a suitable candidate to restore the balance, since it reduces the transit time, might promote beneficial microbial species, and shifts a dominantly proteolytic microbial metabolism to a saccharolytic one. In saccharolysis, amino acids are incorporated for bacterial growth and used as an energy source, rather than being metabolised in precursors of uraemic solutes $[16,18]$. So far, supplementation studies under uraemic conditions in humans have been scarce and unsatisfactory. Meta-analyses underline the weak/suboptimal body of evidence, mainly due to significant study heterogeneity (study population, methodology, duration) and selection of unsuitable fibre types, while dietary assessments are very rarely formally performed [17,19-22]. Moreover, most patients with CKD are on a diet restricting the intake of fibre-rich fruits and vegetables because of their potassium content. Furthermore, low fibre intake was associated with a higher risk of inflammation and mortality in adult CKD patients [23]. Recent studies demonstrated that fibre intake is inadequate in adult as well as paediatric patients with CKD. Daily fibre intake in these patients is far below the recommendations for the healthy population and inversely related to advancing CKD stages [24,25].

In our recently published observational study, we found that patients with the highest fibre intake had lower total and free pCG levels. This study was a cross-sectional analysis, therefore the confounding effect of intra-patient variability in dietary intake and uraemic toxin concentrations could not be excluded. A study in an adult haemodialysis population found a marked intra-patient variability, possibly affecting the significance of the associations between a single concentration of certain toxins (especially total IxS), and outcomes [26]. Awaiting similar trials to determine whether these conclusions are applicable to a paediatric population with varying degrees of kidney dysfunction, we aimed to take into account potential fluctuations within one patient over time, by conducting longitudinal mixed-model analyses, using serial PBUT concentration measurements in blood samples taken at the same time of repeated dietary intake evaluations.

Therefore, the purpose of this study was to evaluate the longitudinal association between dietary fibre intake and total and free serum levels of four selected PBUTs: IxS, pCS, IAA and pCG.

\section{Results}

A total of 61 children ( $9 \pm 5$ years) were eligible for analysis, accounting for a total of 297 visits, with a mean number of 5 visits / patient (range 1-9) and a median follow-up time of 19 (9-22) months. Baseline characteristics are listed in Table 1. Drop out of patients was attributed to dialysis initiation $(n=6)$ or kidney transplantation $(n=2)$. Other missing data originated from missing dietary records or the lack of appropriate coupling of dietary intake with serum PBUT levels the same day. In this CKD cohort, $33 \%$ of the children was diagnosed with CKD stage 1-2,31\% with stage 3, 28\% with stage 4 and $8 \%$ with stage 5 . 
Dietary assessment was obtained through 3-day food records in $27 \%$ of the visits and through $24-\mathrm{h}$ recalls in $73 \%$ of the visits. On average, only $76 \%$ of the Dietary Reference Intake (DRI) for fibre was achieved, while only $23 \%$ of children reached $100 \%$ of the DRI. In contrast, $92 \%$ of children achieved the $100 \%$ DRI for protein. Nutrient intake and PBUT levels across different stages of CKD can be found in Supplementary Tables S1 and S2.

Table 1. Baseline characteristics of the study population $(n=61)$.

\begin{tabular}{|c|c|c|}
\hline Variables & \multicolumn{2}{|c|}{ Values } \\
\hline \multicolumn{3}{|l|}{ Demographics } \\
\hline Age (years) & \multicolumn{2}{|c|}{$9.3 \pm 5.0(1.0-18.0)$} \\
\hline Gender: male & \multicolumn{2}{|c|}{$44(72)$} \\
\hline Transplant recipients & \multicolumn{2}{|c|}{$8(13)$} \\
\hline \multicolumn{3}{|l|}{ Anthropometry } \\
\hline Weight SDS & \multicolumn{2}{|c|}{$-1.0 \pm 1.4$} \\
\hline Height SDS & \multicolumn{2}{|c|}{$-1.2 \pm 1.2$} \\
\hline BMI SDS & \multicolumn{2}{|c|}{$-0.3 \pm 1.3$} \\
\hline $\mathrm{BSA}\left(\mathrm{m}^{2}\right)$ & \multicolumn{2}{|c|}{$1.0 \pm 0.4$} \\
\hline \multicolumn{3}{|l|}{ Cause of kidney failure } \\
\hline Glomerular & \multicolumn{2}{|c|}{$11(18)$} \\
\hline CAKUT & \multicolumn{2}{|c|}{$27(44)$} \\
\hline Cystic disease & \multicolumn{2}{|c|}{$6(10)$} \\
\hline Other non-glomerular & \multicolumn{2}{|c|}{$17(28)$} \\
\hline Laboratory values & & \\
\hline eGFR $\left(\mathrm{ml} / \mathrm{min} / 1.73 \mathrm{~m}^{2}\right)$ & \multicolumn{2}{|c|}{$47.1 \pm 28.9$} \\
\hline \multicolumn{3}{|l|}{ Chronic medication use } \\
\hline Potassium binding resins & \multicolumn{2}{|c|}{$7(12)$} \\
\hline Phosphate binders & \multicolumn{2}{|c|}{$2(3)$} \\
\hline Iron supplements & \multicolumn{2}{|c|}{$22(36)$} \\
\hline Immunosuppressive therapy & \multicolumn{2}{|c|}{$10(16)$} \\
\hline Laxatives & \multicolumn{2}{|c|}{$1(3)$} \\
\hline Antibiotics & \multicolumn{2}{|c|}{$19(31)$} \\
\hline \multicolumn{3}{|l|}{ Nutrient intake } \\
\hline Fibre intake $\left(\mathrm{g} /\right.$ day $\left./ \mathrm{m}^{2}\right)$ & \multicolumn{2}{|c|}{$12.6 \pm 6.8$} \\
\hline \%DRI fibre & \multicolumn{2}{|c|}{$76.0 \pm 36.0$} \\
\hline Protein intake $\left(\mathrm{g} /\right.$ day $\left./ \mathrm{m}^{2}\right)$ & \multicolumn{2}{|c|}{$54.4 \pm 28.4$} \\
\hline \%DRI protein & \multicolumn{2}{|c|}{$220.1 \pm 138.2$} \\
\hline Protein/fibre index & \multicolumn{2}{|c|}{$4.3(2.7-5.8) *$} \\
\hline Energy (kCal/kg/day) & 59. & 30.9 \\
\hline Energy (kCal/day) & 1428 & 504.9 \\
\hline Gut-derived protein-bound uraemic & & \\
\hline & Free & Total \\
\hline $\mathrm{pCG}(\mathrm{mg} / \mathrm{dL})$ & $0.004(0.001-0.013)$ & $0.006(0.001-0.015)$ \\
\hline IAA $(\mathrm{mg} / \mathrm{dL})$ & $0.004(0.002-0.007)$ & $0.042(0.028-0.061)$ \\
\hline $\mathrm{IxS}(\mathrm{mg} / \mathrm{dL})$ & $0.006(0.003-0.015)$ & $0.247(0.101-0.514)$ \\
\hline $\mathrm{pCS}(\mathrm{mg} / \mathrm{dL})$ & $0.017(0.006-0.034)$ & $0.761(0.269-1.372)$ \\
\hline
\end{tabular}

CAKUT: congenital anomalies of the kidney and urinary tract; SDS: standard deviation score; BMI: body mass index; BSA: body surface area; eGFR: estimated glomerular filtration rate according to Schwartz et al.; \%DRI: achieved percentage of the recommended $100 \%$ dietary reference intake; pCG: p-cresylglucuronide; IAA: indole acetic acid; IxS: indoxyl sulfate; pCS: p-cresyl sulfate. Data are expressed as mean \pm standard deviation (SD), number (percentage) or median (25th-75th percentile) as appropriate. ${ }^{*} \mathrm{n}=58$, three patients with a fibre intake of $0 \mathrm{~g} /$ day were excluded for mathematical reasons.

As shown in Table 2, after adjustment for body surface area (BSA), estimated glomerular filtration rate (eGFR) and protein intake, for every $\mathrm{g}$ /day increase in fibre consumption, mixed-model analysis revealed a $1.6 \%(-3.0 \% ;-0.3 \%)$ lower total IAA concentration $(p=0.020)$, whereas free IAA levels were $6.6 \%(-9.3 \% ;-3.7 \%)(p<0.001)$ lower. Further, total pCG levels were 3.0\% $(-5.6 \% ;-0.5 \%)(p=0.021)$ lower, and free serum pCG 3.3\% $(-5.8 \% ;-0.8 \%)(p=0.010)$ lower per $\mathrm{g} /$ day increase in daily fibre consumption. 
Table 2. Association between nutrient (fibre and protein) intake and selected gut-derived proteinbound uraemic toxins.

\begin{tabular}{|c|c|c|c|c|}
\hline \multirow{2}{*}{$\begin{array}{l}\text { Gut-Derived Protein-Bound } \\
\text { Uraemic Toxins (mg/dL) }\end{array}$} & \multirow{2}{*}{ Estimated Mean Ratio } & \multicolumn{2}{|c|}{ Confidence Interval (CI) } & \multirow{2}{*}{$p$} \\
\hline & & Lower 95\% & Upper $95 \%$ & \\
\hline \multicolumn{5}{|l|}{ pCG } \\
\hline \multicolumn{5}{|l|}{ Free concentration } \\
\hline Fibre intake (g/day) & 0.967 & 0.943 & 0.992 & 0.010 \\
\hline Protein intake (g/day) & 1.005 & 0.998 & 1.012 & 0.120 \\
\hline \multicolumn{5}{|l|}{ Total concentration } \\
\hline Fibre intake (g/day) & 0.970 & 0.944 & 0.995 & 0.021 \\
\hline Protein intake (g/day) & 1.006 & 0.998 & 1.012 & 0.116 \\
\hline \multicolumn{5}{|l|}{ IAA } \\
\hline \multicolumn{5}{|l|}{ Free concentration } \\
\hline Fibre intake (g/day) & 0.934 & 0.907 & 0.963 & $<0.001$ \\
\hline Protein intake (g/day) & 1.011 & 1.003 & 1.019 & 0.007 \\
\hline \multicolumn{5}{|l|}{ Total concentration } \\
\hline Fibre intake (g/day) & 0.984 & 0.971 & 0.997 & 0.020 \\
\hline Protein intake (g/day) & 1.001 & 0.998 & 1.005 & 0.430 \\
\hline \multicolumn{5}{|l|}{ IxS } \\
\hline \multicolumn{5}{|l|}{ Free concentration } \\
\hline Fibre intake (g/day) & 0.969 & 0.941 & 0.997 & 0.035 \\
\hline Protein intake (g/day) & 1.005 & 0.997 & 1.012 & 0.259 \\
\hline \multicolumn{5}{|l|}{ Total concentration } \\
\hline Fibre intake (g/day) & 0.986 & 0.965 & 1.006 & 0.196 \\
\hline Protein intake (g/day) & 1.001 & 0.996 & 1.007 & 0.645 \\
\hline \multicolumn{5}{|l|}{ pCS } \\
\hline \multicolumn{5}{|l|}{ Free concentration } \\
\hline Fibre intake (g/day) & 0.975 & 0.953 & 0.998 & 0.034 \\
\hline Protein intake (g/day) & 1.005 & 0.998 & 1.011 & 0.137 \\
\hline \multicolumn{5}{|l|}{ Total concentration } \\
\hline Fibre intake (g/day) & 0.984 & 0.956 & 1.011 & 0.261 \\
\hline Protein intake (g/day) & 1.004 & 0.9962 & 1.012 & 0.282 \\
\hline
\end{tabular}

Total and free uraemic toxin concentrations showed a skewed distribution and were (natural) log-transformed prior to linear mixed-model analysis. Data are expressed as estimated mean ratio and $95 \%$ confidence interval (CI).

For every gram of increment in daily fibre intake, free IxS levels were $3.1 \%(-5.9 \%$; $-0.3 \%)(p=0.035)$ lower, and free pCS were $2.5 \%(-4.7 \% ;-0.3 \%)(p=0.034)$ lower. In contrast, total IxS and pCS serum concentrations were not associated with daily fibre intake (Table 2).

\section{Discussion}

This longitudinal, observational study investigated whether dietary fibre intake is linked to levels of circulating PBUTs in a paediatric CKD cohort. We showed that independent of eGFR, each $\mathrm{g}$ / day fibre intake increase was associated with dose-dependent lower levels of free pCS and IxS and both free and total pCG and IAA concentrations.

Our findings are in line with a study in adult patients with CKD stage $3-4$ which found significantly lower serum IxS levels in a high-fibre versus a low-fibre intake group [27]. Another observational cohort study in adult non-dialysed patients with CKD 4-5 found that a high dietary fibre intake was negatively correlated with both total and free pCS, but not with IxS [28]. To our knowledge, there are no interventional trials supplementing fibre prebiotics in the paediatric CKD population. In adult haemodialysis (HD) patients, beneficial effects of prebiotics on either pCS [29] or (free) IxS [18,30] have been demonstrated. With the exception of one single-blind pilot study, which found a lower level of p-cresol after combined pea hull fiber and inulin supplementation [31], three other trials performed in adult CKD patients who were not on dialysis found no effect on either pCS or IxS after administration of different prebiotics [32-34]. The only two studies evaluating either pCG or IAA in adults with CKD found no significant reduction [32,34]. The essentially negative 
results in adult patients with CKD who were not on dialysis might be attributable to the aforementioned heterogeneity in study design and fibre choice. In addition, dietary intake was often not taken into account in these analyses.

Our data suggest that fibre intake might primarily influence free PBUT concentrations. It is hypothesised that changes in free solute levels of PBUTs are more relevant than total concentrations in the pathophysiology of the uraemic syndrome $[18,35]$. In analogy with studies of protein-bound pharmaceutical agents, the free fraction is regarded as the biologically active one and is considered a better indicator of potential toxicity $[17,18,35-37]$. Several studies investigating pCS concentrations in adult patients either with CKD or on haemodialysis revealed that only the free levels were associated with cardiovascular morbidity and mortality [38-40]. Although still under discussion, it has therefore been suggested that future studies exploring clinically relevant markers and outcomes should take into account both total and free concentrations [35].

Nutrient availability, more specifically the balance between undigested protein and carbohydrate, can modulate microbial metabolism towards either saccharolytic or proteolytic fermentation [16]. The protein/fibre index, taking into account the interplay between the two single nutrients, could thus be informative about the prevailing fermentation profile. In our study, $92 \%$ of the children achieved the daily recommended protein intake, whereas fibre intake was below the daily recommended intake, and only $23 \%$ of the children achieved $100 \%$ DRI for fibre. In addition, in our analysis we adjusted for protein intake. A higher fibre intake in our results is thus coupled to a lower protein/fibre ratio and could be interpreted accordingly. Rossi et al. reported an association between protein/fibre index and serum pCS and IxS levels, while fibre intake alone was associated with pCS and not IxS, and dietary protein intake with neither of these toxins [28]. This is in line with our results, as most likely, the lack of association between protein intake and toxin concentrations is due to a low variability in protein intake, and the variability of the protein/fibre ratio is thus completely due to variation in fibre intake.

Theoretically, a diet with a lower protein/fibre ratio should be reflective of a low nitrogen/carbohydrate ratio in the colon, thus promoting carbohydrate fermentation and subsequently decreasing the production of PBUTs. Our data point to the fact that fibre intake is largely inadequate in children with CKD [25]. Some children who are exclusively fed with a powdered amino acid formula or a formula adapted to the needs of patients with CKD have even no fibre intake at all. In addition, the popular practice of protein restriction in adults with CKD stage 3-5 contrasts sharply with the minimum 100-140\% DRI for proteins to maintain proper growth in children [41]. The low fibre intake in children is therefore far outweighed by the protein intake, resulting in a relatively high baseline protein/fibre ratio in comparison to adults and predisposing to proteolytic microbial activity. Future prebiotic intervention trials in children should thus aim to provide ample fibre content, while allowing sufficient protein intake and avoiding too high potassium loads. Further studies, adding the taxonomic and functional gut microbial profile to the equation, are needed to demonstrate causal relationships and unravel the meaning and relevant clinical implications of these findings.

Fibre supplementation is an appealing strategy to attenuate PBUT generation and its subsequent burden. On population level, early stages of CKD have a much higher prevalence, and an easy and relatively cheap intervention that can delay the progression of kidney disease and dialysis initiation is therefore a worthwhile intervention to further explore. Fibre intake is underappreciated and deserves more attention in the classic nutritional approach of the patient with CKD, which is largely based on sodium, phosphorous and potassium restriction. Dietary fibre is mainly supplied by the consumption of fruits and vegetables, which are often restricted to avoid hyperkalaemia. Such dietary restrictions may, however, worsen dysbiosis and further contribute to uraemic toxicity [42,43].

Limitations of the present study include the observational nature which limits causal inference and possible measurement error inherent to dietary recalls, despite careful evaluation. Transit time and microbiota composition were not assessed. Since urine samples 
of the children were not collected, urinary excretion of the respective uraemic toxins, as markers for generation, could not be estimated. Although we also focused on IAA and pCG, in addition to the well-known IxS and pCS, conclusions cannot be extended to the expanding array of other microbial metabolites of interest. Finally, we only included a small group of patients with CKD stage 4-5 from a single country. Accordingly, cultural and geographic effects could be at play, limiting extrapolation to other settings or populations with different dietary habits.

This study also has several strengths. To our knowledge, this is the first longitudinal study evaluating the effect of fibre intake on PBUTs in a cohort of children with nondialysis CKD. The analysis of multiple PBUT measurements, taking into account the fluctuations within one patient over time, bridges the existence of intra-patient variability of UTs. In addition, nutrient intake was captured through repeated dietary assessments, which allowed us to account for possible intra-individual day-to-day variations as well as seasonality effects. Furthermore, we expanded our focus beyond the most thoroughly studied pCS and IxS, including PCG, which is the less concentrated glucuronidated fraction of p-cresol and IAA, the latter being, just as IxS, a product of tryptophan, originating directly in the colon by an alternative microbial metabolism pathway [44].

\section{Conclusions}

In conclusion, increasing amounts of fibre intake were associated with overall lower PBUT levels, and this independent of eGFR. As most children with CKD have a low fibre intake and a high protein requirement to allow growth, the protein/fibre ratio is re-latively high in comparison to adults, and this predisposes them to proteolytic microbial activity. The present observational findings are helpful to guide the development of wellconceived randomised controlled trials evaluating well-balanced dietary interventions in the paediatric population.

\section{Materials and Methods}

\subsection{Study Population}

For this study, longitudinal data were analysed from the multicentric, prospective, observational UToPaed study, running from 1 September 2015 to 31 December 2017. Children younger than 18 years of age with CKD stage 1-5, including transplant recipients, were eligible for inclusion. In accordance with the eGFR, determined by the updated Schwartz equation [45], CKD patients (defined using the Kidney Disease Improving Global Outcomes (KDIGO) guidelines) were stratified into stages: stage $1: \geq 90 \mathrm{~mL} / \mathrm{min} / 1.73 \mathrm{~m}^{2}$; stage 2 : 60-89 mL/min/1.73 $\mathrm{m}^{2}$; stage $3: 30-59 \mathrm{~mL} / \mathrm{min} / 1.73 \mathrm{~m}^{2}$; stage $4: 15-29 \mathrm{~mL} / \mathrm{min} / 1.73 \mathrm{~m}^{2}$; stage $5:<15 \mathrm{~mL} / \mathrm{min} / 1.73 \mathrm{~m}^{2}$. Children receiving any type of dialysis during follow-up were excluded from the analysis. Other exclusion criteria were the presence of malignancies, active infections or active systemic inflammatory disease. Participants were recruited from the Departments of Paediatric Nephrology of Ghent University Hospital, Antwerp University Hospital, University Hospitals Leuven and University Hospital Saint-Luc, Brussels. Ethical approval was granted by each participating site (number 2600/304, B670201524922; B670201422206). Prior to enrolment, written informed consent was obtained from all parents and patients above the age of 12 .

\subsection{Data Collection and Biochemical Measurements}

Patients were followed prospectively during 24 months. Demographic parameters were recorded at baseline. In addition, clinical parameters (age, height, weight, etc.), dietary intake as detailed below and medical therapy were recorded at each visit. Blood samples were allowed to clot for 20-30 min and then centrifuged $\left(2095 \times g ; 10 \mathrm{~min} ; 4^{\circ} \mathrm{C}\right)$. Serum aliquots were stored at $-80{ }^{\circ} \mathrm{C}$ awaiting batch analysis. Standard lab assays at the Clinical Laboratory of the Ghent University Hospital (Ghent, Belgium) were used to measure biochemical parameters including urea, creatinine (Photometric (Architect c16000, Abbott, IL, USA)), C-reactive protein, albumin and total protein. Concentrations 
of IxS, IAA, pCS and pCG were quantified as previously described [46]. Briefly, for total concentrations, serum samples were deproteinised by heat denaturation, followed by a filtration step through Amicon Ultra $0.5 \mathrm{~mL}$ filters (molecular weight cut-off $30 \mathrm{kDa}$, Millipore Merck, Darmstadt, Germany). For the free fraction, untreated plasma samples were filtered first through the Amicon Ultra Filters. Reversed-phase ultra-performance liquid chromatography (UPLC; Agilent 1290 Infinity device) (Agilent, Santa Clara, CA,

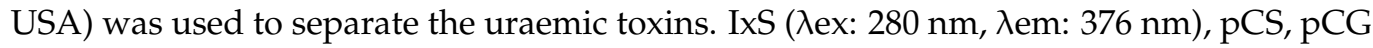
( $\lambda$ ex: $264 \mathrm{~nm}, \lambda \mathrm{em}: 290 \mathrm{~nm}$ ) and IAA ( $\lambda$ ex: $280 \mathrm{~nm}, \lambda \mathrm{em}: 350 \mathrm{~nm}$ ) were detected by an Agilent G1316C fluorescence detector.

\subsection{Dietary Assessment}

Participants' dietary intakes were assessed 3-monthly by either a 3-day food record or a 24-h dietary recall at an aimed 50/50 ratio. Structured 3-day diary templates were completed prior to the visit and reviewed by a trained dietician in face-to-face interviews. The 3-day food record was substituted by a 24-h recall in case parents/patients failed to fill it out or forgot to bring it to the consult, so that dietary data could be coupled to serum PBUT levels from the same day. In order to increase the accuracy of portion size estimation for 24-hour recalls, standardised food models and a food photo album (Portiegroottes boek, Valetudo Consulting, third edition, march 2014) were utilised, along with a manual for the conversion of household measures to weight equivalents [47]. Fibre, protein and energy consumption were calculated by entering dietary data into Evry-Diëtist 6.7.7.0 (Evry BV, Alphen aan den Rijn, The Netherlands), based on the Belgian Branded Food Products Database (Nubel, 5th edition). A search in either the Dutch nutrient database (Nevo, 4th edition) or the online database of trade names (Internubel) was done in case of unknown food items. These were recorded in our coding book, together with standard recipes to ensure reproducibility and accuracy. Non-standard recipes and compound ingredients were broken down into their constituents. Percentage Dietary Reference Intake (\%DRI) for fibre was calculated by expressing the total dietary fibre intake per patient as a percentage of the age-dependent DRI for fibre [48]. Because of the age dependency of the Belgian nutrition recommendations of protein and fibre and the small sample size for analyses in each subgroup, intakes were corrected for body surface area (BSA), calculated by the Haycock formula $(0.024265 \times$ height $(\mathrm{cm}) 0.3964 \times$ weight $(\mathrm{kg}) 0.5378)$. The protein/fibre ratio was calculated.

\subsection{Statistical Analyses}

Descriptive data are expressed as mean \pm standard deviation (SD) or median (25th; 75th percentile), as appropriate. Absolute and relative frequencies are reported for categorical variables.

Linear mixed-effects models were fitted to analyse the association between dietary fibre intake and the four selected gut-derived PBUTs. A compound symmetry covariance matrix was used to take into account a fixed correlation between measurements from the same patient. Linear mixed models for (natural) log-transformed plasma concentrations were fitted with a random intercept for the patient and with fibre intake (g/day), protein intake $(\mathrm{g} /$ day $)$, BSA as a proxy for age $\left(\mathrm{m}^{2}\right)$, eGFR $\left(\mathrm{mL} / \mathrm{min} / 1.73 \mathrm{~m}^{2}\right)$. Exponentiated regression coefficients with corresponding 95\% confidence intervals (CI) are reported. These reflect the geometric mean ratios. Based on the variance inflation factor, there was no indication for multicollinearity between the different explanatory variables.

All hypothesis tests were performed at the two-sided 5\% significance level. Descriptive analyses were performed using SPSS 25.0 (IBM, New York, NY, USA), while the package "lme4" in R version 3.6.1 was used for linear mixed-model analyses. Statistical analyses were executed by an independent biostatistician.

Supplementary Materials: The following are available online at https:/ / www.mdpi.com/2072-665 1/13/3/225/s1, Table S1: Nutrient intake across different CKD stages, Table S2: Serum concentrations of total and free gut-derived, protein-bound uraemic toxins across different CKD stages. 
Author Contributions: Conceptualisation, A.E.A., E.S., S.E., A.R., J.V.W., G.G. and W.V.B.; methodology, A.E.A., E.S., G.G., S.E. and A.R.; formal analysis, A.E.A., A.F., C.V.M. and E.S.; investigation, A.E.A., A.F., C.V.M., E.S., M.V.D., K.V.H., N.G.; resources, A.R., J.V.W., M.V.D., K.V.H., N.G., G.G. and S.E.; data curation, E.S., A.F., C.V.M., A.E.A.; writing-original draft preparation, A.E.A.; writingreview and editing, A.E.A., E.S., S.E., A.R., J.V.W., G.G. and W.V.B.; visualisation, A.E.A., E.S., A.R., G.G. and W.V.B. and S.E.; supervision, S.E.; project administration, A.R. and S.E.; funding acquisition, A.R. and S.E. All authors have read and agreed to the published version of the manuscript.

Funding: This research was funded by the Agency for Innovation by Science and Technology (IWT), 'Applied Biomedical Research with a Primary Societal Goal' (TBM) program in Flanders (Belgium): UToPaed project, grant number IWT-TBM 150195. The APC was funded by the same grant.

Institutional Review Board Statement: The study was conducted according to the guidelines of the Declaration of Helsinki and approved by the Ethics Committee of all participating centres (B670201524922, 18 June 2015).

Informed Consent Statement: Informed consent was obtained from all subjects involved in the study.

Data Availability Statement: The datasets generated during and/or analysed during the current study are available from the corresponding author on reasonable request.

Acknowledgments: The authors wish to thank Sofie Vermeiren, Els Holvoet, Sophie Lobbestael, Tom Mertens, Maria Van Landschoot, An Desloovere, Sofie Eerens, Kimi Lambregts, Katrien Wellens, Jarrik Fransen, Imelda Hamels, Ariadne van Hulle, Katrien Van der Vaerent and Julia Versavau for their assistance.

Conflicts of Interest: J.V.W. received lecture fees from Vitaflo and is member of the European Society for Paediatric Nephrology (ESPN) nutritional task force (with Vitaflo grant). The other authors have no conflicts of interest to declare.

\section{References}

1. Mitsnefes, M.M. Cardiovascular disease in children with chronic kidney disease. J. Am. Soc. Nephrol. 2012, 23, 578-585. [CrossRef]

2. Snauwaert, E.; Van Biesen, W.; Raes, A.; Glorieux, G.; Vanholder, R.; Walle, J.V.; Eloot, S. A plea for more uremic toxin research in children with chronic kidney disease. Pediatr. Nephrol. 2018, 33, 921-924. [CrossRef] [PubMed]

3. Tong, A.; Wong, G.; McTaggart, S.; Henning, P.; Mackie, F.; Carroll, R.P.; Howard, K.; Craig, J.C. Quality of life of young adults and adolescents with chronic kidney disease. J. Pediatr. 2013, 163, 1179-1185. [CrossRef] [PubMed]

4. Ingelfinger, J.R.; Kalantar-Zadeh, K.; Schaefer, F. Averting the legacy of kidney disease-Focus on childhood. Kidney Dis. 2016, 2, 46-52. [CrossRef] [PubMed]

5. Meyer, T.W.; Hostetter, T.H. Uremia. N. Engl. J. Med. 2007, 357, 1316-1325. [CrossRef] [PubMed]

6. Aronov, P.A.; Luo, F.J.-G.; Plummer, N.S.; Quan, Z.; Holmes, S.; Hostetter, T.H.; Meyer, T.W. Colonic contribution to uremic solutes. J. Am. Soc. Nephrol. 2011, 22, 1769-1776. [CrossRef]

7. Mair, R.D.; Sirich, T.L.; Plummer, N.S.; Meyer, T.W. Characteristics of colon-derived uremic solutes. Clin. J. Am. Soc. Nephrol. 2018, 13, 1398-1404. [CrossRef] [PubMed]

8. Evenepoel, P.; Poesen, R.; Meijers, B. The gut-Kidney axis. Pediatr. Nephrol. 2017, 32, 2005-2014. [CrossRef]

9. Vanholder, R.; Pletinck, A.; Schepers, E.; Glorieux, G.L. Biochemical and clinical impact of organic uremic retention solutes: A Comprehensive Update. Toxins 2018, 10, 33. [CrossRef]

10. Liabeuf, S.; Glorieux, G.; Lenglet, A.; Diouf, M.; Schepers, E.; Desjardins, L.; Choukroun, G.; Vanholder, R.; Massy, Z.A.; European Uremic Toxin (EUTox) Work Group. Does p-cresylglucuronide have the same impact on mortality as other protein-bound uremic toxins? PLoS ONE 2013, 8, e67168. [CrossRef]

11. Liabeuf, S.; Desjardins, L.; Massy, Z.A.; Brazier, F.; Westeel, P.F.; Mazouz, H.; Titeca-Beauport, D.; Diouf, M.; Glorieux, G.; Vanholder, R.; et al. Levels of indoxyl sulfate in kidney transplant patients, and the relationship with hard outcomes. Circ. J. 2016, 80, 722-730. [CrossRef] [PubMed]

12. Gryp, T.; Vanholder, R.; Vaneechoutte, M.; Glorieux, G. p-Cresyl Sulfate. Toxins 2017, 9, 52. [CrossRef] [PubMed]

13. Vaziri, N.D.; Zhao, Y.-Y.; Pahl, M.V. Altered intestinal microbial flora and impaired epithelial barrier structure and function in CKD: The nature, mechanisms, consequences and potential treatment. Nephrol. Dial. Transplant. 2015, 31, 737-746. [CrossRef]

14. Vaziri, N.D.; Wong, J.; Pahl, M.; Piceno, Y.M.; Yuan, J.; DeSantis, T.Z.; Ni, Z.; Nguyen, T.-H.; Andersen, G.L. Chronic kidney disease alters intestinal microbial flora. Kidney Int. 2013, 83, 308-315. [CrossRef]

15. Wong, J.; Piceno, Y.M.; DeSantis, T.Z.; Pahl, M.; Andersen, G.L.; Vaziri, N.D. Expansion of urease- and uricase-containing, indoleand p-cresol-forming and contraction of short-chain fatty acid-producing intestinal microbiota in ESRD. Am. J. Nephrol. 2014, 39, 230-237. [CrossRef]

16. Evenepoel, P.; Meijers, B.K.; Bammens, B.R.; Verbeke, K. Uremic toxins originating from colonic microbial metabolism. Kidney Int. 2009, 76, S12-S19. [CrossRef] [PubMed] 
17. Vanholder, R.; Glorieux, G. The intestine and the kidneys: A bad marriage can be hazardous. Clin. Kidney J. 2015, 8, 168-179. [CrossRef]

18. Sirich, T.L.; Plummer, N.S.; Gardner, C.D.; Hostetter, T.H.; Meyer, T.W. Effect of increasing dietary fiber on plasma levels of colon-derived solutes in hemodialysis patients. Clin. J. Am. Soc. Nephrol. 2014, 9, 1603-1610. [CrossRef]

19. Rossi, M.; Klein, K.; Johnson, D.W.; Campbell, K.L. Pre-, Pro-, and synbiotics: Do they have a role in reducing uremic toxins? A systematic review and meta-analysis. Int. J. Nephrol. 2012, 2012, 1-20. [CrossRef]

20. Wu, M.; Cai, X.; Lin, J.; Zhang, X.; Scott, E.M.; Li, X. Association between fibre intake and indoxyl sulphate/P-cresyl sulphate in patients with chronic kidney disease: Meta-analysis and systematic review of experimental studies. Clin. Nutr. 2019, 38, 2016-2022. [CrossRef]

21. Pisano, A.; D’Arrigo, G.; Coppolino, G.; Bolignano, D. Biotic supplements for renal patients: A Systematic review and metaanalysis. Nutrients 2018, 10, 1224. [CrossRef] [PubMed]

22. McFarlane, C.; Ramos, C.I.; Johnson, D.W.; Campbell, K.L. Prebiotic, probiotic, and synbiotic supplementation in chronic kidney disease: A systematic review and meta-analysis. J. Ren. Nutr. 2019, 29, 209-220. [CrossRef]

23. Krishnamurthy, V.M.R.; Wei, G.; Baird, B.C.; Murtaugh, M.; Chonchol, M.B.; Raphael, K.L.; Greene, T.; Beddhu, S. High dietary fiber intake is associated with decreased inflammation and all-cause mortality in patients with chronic kidney disease. Kidney Int. 2012, 81, 300-306. [CrossRef]

24. Kalantar-Zadeh, K.; Kopple, J.D.; Deepak, S.; Block, D.; Block, G. Food intake characteristics of hemodialysis patients as ob-tained by food frequency questionnaire. J. Ren. Nutr. 2002, 12, 17-31. [CrossRef] [PubMed]

25. El Amouri, A.; Snauwaert, E.; Foulon, A.; Moortel, C.V.; Van Dyck, M.; Van Hoeck, K.; Godefroid, N.; Glorieux, G.; Van Biesen, W.; Walle, J.V.; et al. Dietary fibre intake is low in paediatric chronic kidney disease patients but its impact on levels of gut-derived uraemic toxins remains uncertain. Pediatr. Nephrol. 2021, 1-7. [CrossRef]

26. Eloot, S.; Van Biesen, W.; Roels, S.; Delrue, W.; Schepers, E.; Dhondt, A.; Vanholder, R.; Glorieux, G. Spontaneous variability of pre-dialysis concentrations of uremic toxins over time in stable hemodialysis patients. PLoS ONE 2017, 12, e0186010. [CrossRef]

27. Lu, L.; Huang, Y.-F.; Wang, M.-Q.; Chen, D.-X.; Wan, H.; Wei, L.-B.; Xiao, W. Dietary fiber intake is associated with chronic kidney disease (CKD) progression and cardiovascular risk, but not protein nutritional status, in adults with CKD. Asia Pac. J. Clin. Nutr. 2017, 26, 598-605.

28. Rossi, M.; Johnson, D.; Xu, H.; Carrero, J.; Pascoe, E.; French, C.; Campbell, K. Dietary protein-fiber ratio associates with circulating levels of indoxyl sulfate and p-cresyl sulfate in chronic kidney disease patients. Nutr. Metab. Cardiovasc. Dis. 2015, 25, 860-865. [CrossRef] [PubMed]

29. Meijers, B.K.I.; De Preter, V.; Verbeke, K.; Vanrenterghem, Y.; Evenepoel, P. p-Cresyl sulfate serum concentrations in haemodialysis patients are reduced by the prebiotic oligofructose-enriched inulin. Nephrol. Dial. Transplant. 2009, 25, 219-224. [CrossRef]

30. Esgalhado, M.; Kemp, J.A.; Azevedo, R.; Paiva, B.R.; Stockler-Pinto, M.B.; Dolenga, C.J.; Borges, N.A.; Nakao, L.S.; Mafra, D. Could resistant starch supplementation improve inflammatory and oxidative stress biomarkers and uremic toxins levels in hemodialysis patients? A pilot randomized controlled trial. Food Funct. 2018, 9, 6508-6516. [CrossRef]

31. Salmean, Y.A.; Segal, M.S.; Palii, S.P.; Dahl, W.J. Fiber Supplementation lowers plasma p-Cresol in chronic kidney disease patients. J. Ren. Nutr. 2015, 25, 316-320. [CrossRef] [PubMed]

32. Poesen, R.; Evenepoel, P.; De Loor, H.; Delcour, J.A.; Courtin, C.M.; Kuypers, D.; Augustijns, P.; Verbeke, K.; Meijers, B. The influence of prebiotic arabinoxylan oligosaccharides on microbiota derived uremic retention solutes in patients with chronic kidney disease: A randomized controlled trial. PLoS ONE 2016, 11, e0153893. [CrossRef] [PubMed]

33. Elamin, S.; Alkhawaja, M.J.; Bukhamsin, A.Y.; Idris, M.A.S.; Abdelrahman, M.M.; Abutaleb, N.K.; Housawi, A.A. Gum arabic reduces c-reactive protein in chronic kidney disease patients without affecting urea or indoxyl sulfate levels. Int. J. Nephrol. 2017, 2017, 1-6. [CrossRef]

34. Ramos, C.I.; Armani, R.G.; Canziani, M.E.F.; Dalboni, M.A.; Dolenga, C.J.R.; Nakao, L.S.; Campbell, K.L.; Cuppari, L. Effect of prebiotic (fructooligosaccharide) on uremic toxins of chronic kidney disease patients: A randomized controlled trial. Nephrol. Dial. Transplant. 2019, 34, 1876-1884. [CrossRef]

35. Evenepoel, P.; Glorieux, G.; Meijers, B. p-cresol sulfate and indoxyl sulfate: Some clouds are gathering in the uremic toxin sky. Kidney Int. 2017, 92, 1323-1324. [CrossRef]

36. Bres, E.; Koppe, L. Is there still a place for prebiotics in chronic kidney disease? Nephrol. Dial. Transplant. 2019, 34, 1812-1816. [CrossRef] [PubMed]

37. Schmidt, S.; Gonzalez, D.; Derendorf, H. Significance of protein binding in pharmacokinetics and pharmacodynamics. J. Pharm. Sci. 2010, 99, 1107-1122. [CrossRef]

38. Liabeuf, S.; Barreto, D.V.; Barreto, F.C.; Meert, N.; Glorieux, G.; Schepers, E.; Temmar, M.; Choukroun, G.; Vanholder, R.; Massy, Z.A.; et al. Free p-cresylsulphate is a predictor of mortality in patients at different stages of chronic kidney disease. Nephrol. Dial. Transplant. 2009, 25, 1183-1191. [CrossRef]

39. Shafi, T.; Meyer, T.W.; Hostetter, T.H.; Melamed, M.L.; Parekh, R.S.; Hwang, S.; Banerjee, T.; Coresh, J.; Powe, N.R. Free levels of selected organic solutes and cardiovascular morbidity and mortality in hemodialysis patients: Results from the retained organic solutes and clinical outcomes (ROSCO) investigators. PLOS ONE 2015, 10, e0126048. [CrossRef]

40. Meijers, B.; Bammens, B.; De Moor, B.; Verbeke, K.; Vanrenterghem, Y.; Evenepoel, P. Free p-cresol is associated with cardiovascular disease in hemodialysis patients. Kidney Int. 2008, 73, 1174-1180. [CrossRef] 
41. Foundation, N.K. KDOQI clinical practice guideline for nutrition in children with CKD: 2008 update. Am. J. Kidney Dis. 2009, 53, S11-S104. [CrossRef] [PubMed]

42. Poesen, R.; Windey, K.; Neven, E.; Kuypers, D.; De Preter, V.; Augustijns, P.; D’Haese, P.; Evenepoel, P.; Verbeke, K.; Meijers, B. The influence of CKD on colonic microbial metabolism. J. Am. Soc. Nephrol. 2015, 27, 1389-1399. [CrossRef]

43. Cupisti, A.; D'Alessandro, C.; Gesualdo, L.; Cosola, C.; Gallieni, M.; Egidi, M.F.; Fusaro, M. Non-traditional aspects of renal diets: Focus on fiber, alkali and vitamin k1 intake. Nutrients 2017, 9, 444. [CrossRef] [PubMed]

44. Snelson, M.; Kellow, N.J.; Coughlan, M.T. Modulation of the gut microbiota by resistant starch as a treatment of chronic kidney diseases: Evidence of efficacy and mechanistic insights. Adv. Nutr. 2019, 10, 303-320. [CrossRef] [PubMed]

45. Schwartz, G.J.; Muñoz, A.; Schneider, M.F.; Mak, R.H.; Kaskel, F.; Warady, B.A.; Furth, S.L. New equations to estimate GFR in children with CKD. J. Am. Soc. Nephrol. 2009, 20, 629-637. [CrossRef]

46. Gryp, T.; De Paepe, K.; Vanholder, R.; Kerckhof, F.-M.; Van Biesen, W.; Van de Wiele, T.; Verbeke, F.; Speeckaert, M.; Joossens, M.; Couttenye, M.M.; et al. Gut microbiota generation of protein-bound uremic toxins and related metabolites is not altered at different stages of chronic kidney disease. Kidney Int. 2020, 97, 1230-1242. [CrossRef] [PubMed]

47. Bellemans, M.; De Mayer, M. Maten en Gewichten: Handleiding voor een Gestandardiseerde Kwantificering van Voedingsmiddelen, 2nd ed.; Hoge Gezondheidsraad: Brussel, Belgium, 2005. (In Dutch)

48. Gezondheidsraad, H. Voedingsaanbevelingen voor België-2016; Hoge Gezondheidsraad: Brussel, Belgium, 2016. (In Dutch) 